\title{
Hubungan Derajat Depresi dengan Nyeri Kepala pada Penderita yang Berobat Di Poliklinik Saraf RSU Anutapura Palu Tahun 2018
}

\author{
Karmila Sari Sulhaji ${ }^{1}$, Ruslan Ramlan Ramli ${ }^{2}$ \\ ${ }^{1}$ Program Studi Pendidikan Dokter, Fakultas Kedokteran, Universitas Al Khairaat Palu \\ ${ }^{2}$ Bagian Anatomi Fakultas Kedokteran, Universitas Al Khairaat Palu
}

Email: ramlanruslan@gmail.com

\begin{abstract}
Depression is a mental disorder characterized by the appearance of symptoms of decreased mood, loss of interest in something, feelings of guilt, sleep disturbances or appetite, loss of energy, and decreased concentration. Depression is divided into three, namely mild depression, moderate depression and severe depression. Headache is pain or discomfort in the entire head area with the lower border of the chin to the back of the head. The relationship between mental disorders such as depression and headache is important to know because depression is one of the main causes of inability in one's life and mental disorders in patients with headache will provide obstacles in the treatment of headache. Headache patients with depression use health services more because of the symptoms of headaches that often recur and last a long time. This study aims to determine the relationship between the degree of depression and headache in patients treated at the RSU nerve polyclinic. Anutapura in 2018. This research is an analytic case control study design. Data collection was done by interviewing questionnaires to all headache patients grouped into acute headache and chronic headache. The analysis was done by Chi-square test using SPSS 21 . At the significance limit $\alpha$ $=5 \%$. The results of the study were from 41 acute headache samples and 41 chronic headache samples found a significant relationship $(\mathrm{p}=0.026)$ between mild depression with chronic headache with an odds ratio of 2.752 . Also found a significant relationship between moderate depression with acute headache with an Odds ratio of 2.752. The conclusion is that the degree of depression is associated with headache. Mild depression is a risk factor for chronic headache while moderate depression is a risk factor for acute headache.
\end{abstract}

Keywords: Depression, degree of depression, headache.

\section{Abstrak}

Depresi merupakan gangguan mental yang ditandai dengan munculnya gejala penurunan mood, kehilangan minat terhadap sesuatu, perasaan bersalah, gangguan tidur atau nafsu makan, kehilangan energi, dan penurunan konsentrasi. Depresi terbagi atas tiga yaitu depresi ringan, depresi sedang dan depresi berat. Nyeri kepala merupakan rasa nyeri atau rasa tidak mengenakkan pada seluruh daerah kepala dengan batas bawah dari dagu sampai ke daerah belakang kepala. Hubungan antara gangguan jiwa seperti depresi dan nyeri kepala penting untuk diketahui karena depresi merupakan salah satu penyebab utama ketidakmampuan di dalam kehidupan seseorang dan gangguan jiwa pada pasien dengan nyeri kepala akan memberikan hambatan dalam terapi nyeri kepala. Pasien nyeri kepala dengan depresi lebih banyak menggunakan layanan kesehatan karena gejala nyeri kepala yang sering berulang dan berlangsung lama. Penelitian ini bertujuan untuk mengetahui adanya hubungan antara derajat depresi dengan nyeri kepala pada penderita yang berobat di poliklinik saraf RSU. Anutapura tahun 2018. Penelitian ini merupakan analitik dengan desain case control study. Pengumpulan data dilakukan dengan wawancara menggunakan kuesioner kepada semua pasien nyeri kepala yang di kelompokkan menjadi nyeri kepala akut dan nyeri kepala kronis. Dilakukan analisis dengan uji Chi-square menggunakan SPSS 21. Pada batas kemaknaan $\alpha=5 \%$. Hasil penelitian adalah dari 41 sampel nyeri kepala akut dan 41 sampel nyeri kepala kronis ditemukan hubungan bermakna $(p=0,026)$ antara depresi ringan dengan nyeri kepala kronis dengan Odds Ratio sebesar 2,752 . Juga ditemukan hubungan yang bermakna antara depresi sedang dengan nyeri kepala akut dengan Odds ratio sebesar 2,752. Kesimpulan bahwa derajat depresi berhubungan dengan nyeri kepala. Depresi ringan merupakan faktor resiko nyeri kepala kronis sedangkan depresi sedang merupakan faktor resiko nyeri kepala akut.

Kata kunci : depresi, derajat depresi, nyeri kepala. 


\section{PENDAHULUAN}

Depresi merupakan gangguan mental yang ditandai dengan munculnya gejala penurunan mood, kehilangan minat terhadap sesuatu, perasaan bersalah, gangguan tidur atau nafsu makan, kehilangan energi, dan penurunan konsentrasi ${ }^{1}$. Depresi terbagi atas tiga yaitu depresi ringan, depresi sedang dan depresi berat ${ }^{2}$.

Menurut World Health Organization, pada tahun 2016 angka kejadian depresi diperkirakan mempengaruhi 350 juta orang diseluruh dunia, sedangkan menurut BioMed Central di seluruh dunia pada tahun 2011 sebanyak 121 juta orang mengalami depresi, dan di Amerika Serikat pada tahun 2010 sebanyak 8 juta orang mengalami depresi. Di Indonesia pada tahun 2013 sebanyak 6,0\% dan di Sulawesi Tengah pada tahun 2013 sebanyak 11,6\%, sedangkan di kota Palu belum ada data tentang angka kejadian depresi. Berdasarkan catatan medis Rumah Sakit Umum Anutapura Palu, tercatat kasus depresi setiap tahunnya tidak menentu, dengan jumlah kasus pada tahun 2014 sebanyak 19 kasus, pada tahun 2015 sebanyak 26 kasus, dan pada tahun 2016 sebanyak 23 kasus.

Nyeri kepala merupakan rasa nyeri atau rasa tidak mengenakkan pada seluruh daerah kepala dengan batas bawah dari dagu sampai ke daerah belakang kepala (daerah oksipital dan sebahagian daerah tengkuk) ${ }^{3}$. Nyeri kepala disebabkan oleh kelainan vaskuler, jaringan saraf, gigi geligi, orbita, hidung dan sinus paranasal, jaringan lunak di kepala, kulit, jaringan subkutan otot, dan periosteum di kepala ${ }^{4}$. Nyeri kepala dapat di bagi tiga kelompok berdasarkan onsetnya yaitu nyeri kepala akut, sub akut dan kronik 5 .

Secara global, persentase populasi orang dewasa dengan gangguan nyeri kepala $46 \%$ antara lain $11 \%$ migrain, 42\% Tension Type Headache dan 3\% untuk Chronic Daily Headache (Silberstein, 2006;6(9C):S885S890 dan Evans, 2007;11: 47-52). Berdasarkan catatan medis RSU Anutapura Palu, angka kejadian nyeri kepala di RSU Anutapura Palu pada tahun 2015 yaitu sebanyak 358 kasus dan pada tahun 2016 sebanyak 311 kasus.

Hubungan antara gangguan jiwa seperti depresi dan nyeri kepala penting untuk di diketahui karena depresi merupakan salah satu penyebab utama ketidakmampuan di dalam kehidupan seseorang dan gangguan jiwa pada pasien dengan nyeri kepala akan memberikan hambatan dalam terapi nyeri kepala. Pasien nyeri kepala dengan depresi lebih banyak menggunakan layanan kesehatan karena gejala nyeri kepala yang sering berulang dan berlangsung lama ${ }^{6}$. Sebuah penelitian melaporan bahwa pasien nyeri kepala yang di sertai dengan gangguan jiwa menunjukkan kualitas hidup yang rendah karena sulit bekerja secara maksimal dan kehilangan minat untuk beraktivitas ${ }^{7}$. 


\section{METODOLOGI}

Penelitian ini menggunakan metode penelitian Observasional Analitik dengan pendekatan Case Control, yang terdiri dari nyeri kepala akut dan nyeri kepala kronis di Poliklinik Saraf RSU Anutapura Palu, dilakukan mulai tanggal 7 April sampai tanggal 7 Juni 2018. Populasi pada penelitian ini adalah semua pasien nyeri kepala yang di kelompokkan menjadi nyeri kepala akut dan nyeri kepala kronis, yang telah didiagnosis menderita nyeri kepala yang dikelompokkan menjadi nyeri kepala akut dan nyeri kepala kronis yang datang di Poliklinik Saraf RSU Anutapura Palu tahun 2018 sesuai dengan kriteria penelitian.

Besar sampel dalam penelitian ini menggunakan analitik kategori tidak berpasangan dengan rumus:

$\mathbf{n} \mathbf{1}=\mathbf{n} \mathbf{2}=\left(\frac{Z \propto \sqrt{2 P Q}+Z \beta \sqrt{P 1 Q 1+P 2 Q 2}}{P 1-P 2}\right)^{2}$
Pengambilan sampel dalam penelitian ini adalah dengan teknik consecutive sampling. Analisis data yang digunakan untuk mengetahui hubungan derajat depresi dengan nyeri kepala adalah analisis bivariat dengan metode chi square. Metode ini dugunakan untuk mencari hubungan dan membuktikan hipotesis dua variable. Data diolah dengan menggunakan perangkat lunak komputer program SPSS 21.0.

\section{HASIL DAN PEMBAHASAN}

Hubungan Derajat Depresi dengan Nyeri Kepala pada Penderita yang Berobat di Poliklinik Saraf RSU Anutapura Palu Tahun 2018

Hubungan derajat depresi dengan nyeri kepala. Dari variabel tersebut di ditemukan hubungan yang bermakna antara derajat depresi dengan nyeri kepala karena nilai p>0,05 pada uji Chi-Square, dapat dilihat pada tabel 1 dan tabel 2 .

Tabel 1. Hubungan Derajat Depresi dengan Nyeri Kepala Akut pada Penderita yang Berobat di Poliklinik Saraf RSU Anutapura Palu Tahun 2018

\begin{tabular}{|c|c|c|c|c|c|c|c|}
\hline \multirow{2}{*}{ No } & \multirow{2}{*}{ Derajat Depresi } & $\begin{array}{c}\text { Nyeri Kepala Akut } \\
\text { (Kasus) }\end{array}$ & $\begin{array}{c}\text { Nyeri } \\
\text { Kepala Kronis } \\
\text { (Kontrol) }\end{array}$ & $\mathrm{P}$ & OR & \multicolumn{2}{|r|}{$\mathrm{CI}$} \\
\hline & & $\begin{array}{l}\mathrm{n} \\
(\%)\end{array}$ & $\begin{array}{l}\mathrm{n} \\
(\%)\end{array}$ & \multirow{3}{*}{0,026} & \multirow{3}{*}{2,752} & Upper & Lower \\
\hline \multirow[b]{2}{*}{1.} & $\begin{array}{ll}\text { a. } & \text { Derajat } \\
& \text { Depresi } \\
\text { Ringan }\end{array}$ & $\begin{array}{l}18 \\
(43,9 \%)\end{array}$ & $\begin{array}{l}28 \\
(68,3 \%)\end{array}$ & & & \multirow{2}{*}{0,147} & \multirow{2}{*}{0,895} \\
\hline & $\begin{array}{ll}\text { b. } & \text { Derajat } \\
& \text { Depresi } \\
\text { Sedang }\end{array}$ & $\begin{array}{l}23 \\
(56,1 \%)\end{array}$ & $\begin{array}{l}13 \\
(31,7)\end{array}$ & & & & \\
\hline
\end{tabular}

Keterangan: nilai $\mathrm{p}$ dihitung berdasarkan uji Chi-square. Nilai $\mathrm{p}$ bermakna 
Tabel 2. Hubungan Derajat Depresi dengan Nyeri Kepala Kronis pada Penderita yang Berobat di Poliklinik Saraf RSU Anutapura Palu Tahun 2018

\begin{tabular}{|c|c|c|c|c|c|c|c|}
\hline \multirow[t]{2}{*}{ No } & \multirow[t]{2}{*}{ Derajat Depresi } & $\begin{array}{c}\text { Nyeri Kepala } \\
\text { Kronis } \\
\text { (Kasus) }\end{array}$ & $\begin{array}{c}\text { Nyeri Kepala } \\
\text { Akut } \\
\text { (Kontrol) }\end{array}$ & $\mathrm{P}$ & OR & \multicolumn{2}{|c|}{ CI } \\
\hline & & $\begin{array}{c}\mathrm{n} \\
(\%)\end{array}$ & $\begin{array}{c}\mathrm{n} \\
(\%)\end{array}$ & \multirow{3}{*}{0,026} & \multirow{3}{*}{2,752} & Upper & Lower \\
\hline \multirow{2}{*}{1.} & $\begin{array}{l}\text { Derajat } \\
\text { Depresi } \\
\text { Ringan }\end{array}$ & $\begin{array}{c}28 \\
(68,3 \%)\end{array}$ & $\begin{array}{c}18 \\
(43,9)\end{array}$ & & & \multirow{2}{*}{1,117} & \multirow{2}{*}{6,781} \\
\hline & $\begin{array}{l}\text { b. Derajat Depresi } \\
\text { Sedang }\end{array}$ & $\begin{array}{c}13 \\
(31,7 \%)\end{array}$ & $\begin{array}{c}23 \\
(56,1)\end{array}$ & & & & \\
\hline
\end{tabular}

Keterangan: nilai p dihitung berdasarkan uji Chi-square. Nilai p bermakna 
Berdasarkan pada tabel 1 dan tabel 2 dapat dilihat bahwa ada hubungan yang bermakna $(\mathrm{p}<0,05)$ antara derajat depresi dengan nyeri kepala. Dari 46 orang yang mengalami depresi ringan, 28 orang diantaranya $(68,3 \%)$ menderita nyeri kepala kronis dan 18 orang $(43,9 \%)$ menderita nyeri kepala akut, sedangkan dari 36 orang yang mengalami depresi sedang, 13 orang diantaranya $(31,7 \%)$ menderita nyeri kepala kronis dan 23 orang $(56,1 \%)$ menderita nyeri kepala akut. Ini menunjukan bahwa depresi sedang merupakan faktor resiko terjadinya nyeri kepala akut, sedangkan depresi ringan merupakan faktor resiko terjadinya nyeri kepala kronis.

\section{Hubungan Deraja Depresi dengan Nyeri Kepala}

Hubungan antara depresi dan nyeri kepala telah dijelaskan dalam "International Classification of Headache Disorders (ICHD)". Dimana dikatakan bahwa nyeri kepala yang di akibatkan oleh gangguan jiwa digolongkan sebagai nyeri kepala sekunder. Depresi memperberat gejala nyeri kepala dengan menambah frekuensi dan memperberat gejala nyeri kepala serta menyebabkan pengobatan kurang berkesan 8.

Berdasarkan uji statistik dengan menggunakan program SPSS versi 21 , diperoleh nilai $\mathrm{P}=0,026$ $(\mathrm{P}<0,05)$ sehingga dapat disimpulkan bahwa derajat depresi mempunyai hubungan yang bermakna dengan nyeri kepala. Sesuai dengan hasil penelitian dapat dilihat bahwa derajat depresi merupakan faktor risiko terjadinya nyeri kepala pada penderita yang berobat di Poliklinik Saraf RSU Anutapura Palu.

Hasil penelitian ini sejalan dengan penelitan yang dilakukan oleh Setiawan J. C, et al pada tahun 2013 dimana didapatkan hasil yang bermakna dengan nilai $\mathrm{p}=0,023(\mathrm{p}<0,05)$ yaitu sebagian besar suasana perasaan depresif berhubungan dengan nyeri kepala ${ }^{9,10}$.

Gangguan depresi dapat terjadi bersama-sama dengan nyeri kepala sebagai komorbiditas yang berhubungan dengan intensitas nyeri kepala yang lebih berat dan menetap, penurunan kualitas hidup, prognosis yang lebih buruk, menjadi menahunnya penyakit, ketidakpatuhan pengobatan, respons pengobatan yang lebih buruk, dan biaya pengobatan yang membesar serta berhubungan dengan awitan, perburukan, dan perjalanan nyeri kepala menjadi kronis, baik melalui proses biologik maupun psikologik. Meskipun nyeri kepala berhubungan dengan skor psikopatologi secara bermakna, tetapi arah hubungannya belum jelas ${ }^{9,11}$.

\section{KESIMPULAN}

Berdasarkan hasil penelitian dari 82 responden di Poliklinik Saraf RSU Anutapura Palu Tahun 2018 tentang hubungan derajat depresi dengan nyeri kepala pada penderita yang berobat di Poliklinik Saraf, diperoleh kesimpulan bahwa: Derajat depresi berhubungan dengan nyeri kepala. Depresi ringan merupakan faktor resiko terjadinya nyeri kepala kronis 
sedangkan depresi sedang merupakan faktor resiko

terjadinya nyeri kepala akut.

\section{DAFTAR PUSTAKA}

1. World Health Organization. Depression. [Online]. 2013 Feb [cited 2017 Dec 08]; available from: URL:http://www.who.int/mediacentre/factsheets/f s369/en/.

2. Maslim, R. Buku Saku Diagnosis Gangguan Jiwa Rujukan Ringkas dari PPDGJ-III dan DSM-5. Jakarta: Bagian Ilmu Kedokteran Jiwa FK Unika Atma Jaya; 2013.

3. Sjahrir, H., 2008. Nyeri Kepala dan Vertigo. In : Yogyakarta, Pustaka Cendekia Press, pp. 141-18.

4. Sudoyo, Aru W, et al. 2009. Buku Ajar: Ilmu Penyakit Dalam. Ed kedua. Jakarta: FK UI.

5. Anurogo, Dito. Tension Type Headache. 2014 [online] 41(3):186; [cited 2016 jul 26]; Available from:

URL:http://kalbemed.com/Portals/6/07_214Tensi on\%20Type\%20Headache.pdf.

6. Blaaw BA. Dyb G, Hagen K, Holmen TL, Linde M, Wentzel-larsen $\mathrm{T}$ et al. 2014. Anxiety, Depression and Behavioral Problem among Adolescents with Recurrent headache: the YoungHUNT study. The Journal of Headache and Pain 06;15:1-38.

7. Zebenholzer K. Lechner A. Broessner $\mathrm{G}$ et al. 2016. Impact of Depression and Anxiety on burden and Management of episodic and chronic headache- a cross-sectional multicentre study in eight Austrian headache centres. The Journal of Headache and Pain 02;17:1-10.

8. International Headache Society (IHS). 2013. The International Classification of Headache Disorders, 3rd edition. Cephalgia: 33(9) 629-808.

9. The International Classification of Headache Disorders. [online]. 2004 [cited 2016 jul 26]; Available from: URL:http://www.ihsclassification.org.

10. Setiawan, J.C., et al. 2013. Hubungan antara Gejala Gangguan Depresi dan Tension-Type Headache (TTH): Studi Eksploratif. MKB, Volume 45 No.1.

11. Rori, A.A., et al. 2016. Gambaran Nyeri Kepala pada Mahasiswa Pemain Game Komputer di Fakultas Kedokteran Universitas Sam Ratulangi Angkatan 2012. Jurnal e-Clinic (eCl), Volume 4 Nomor 1 